\title{
Immunohistochemical Expression of Heparanase-2 in Psoriasis
}

Rehab Monir Samaka ${ }^{1}$, Mohammed Abd Elmoneim Shoieb ${ }^{2}$, Walaa Adel Abdo*3

Departments ${ }^{1}$ Pathology and ${ }^{2}$ Dermatology, Faculty of Medicine, Menoufia University, Shebin El Kom, Menoufia Governorate, ${ }^{3}$ Dermatology Department, Sammanud Central Hospital, Gharbeya Governorate Egypt. *Corresponding author: Walaa Adel Abdo, Mobile: (+20)01227287215, E-mail: Walaa_ade19@yahoo.com

\section{ABSTRACT}

Background: Psoriasis is a chronic, inflammatory immune mediated skin disease characterized by dense infiltrates of immunocytes especially macrophages. Cross talk between immunocytes and keratinocytes is thought to mediate the disease. Hparanase 2 inhibits activity of Heparanase 1 which is involved in this cross talk by degradation of heparin sulphate chains in the basement membrane and extra cellular matrix (ECM).

Objective: To assess the of Heparanase 2 in psoriasis through its immunohistochemical expression in lesional and perilesional skin of psoriasis patients.

Patients and Methods: This prospective case control study was carried out on a total number of 60 subjects, they included 30 patients with chronic plaque psoriasis and 30 age and gender matched apparently normal subjects as control group. Skin biopsies were taken for immunohistochemical evaluation of Heparanase 2 expression.

Results: Our results showed significant difference between lesional, perilesional and control groups regarding the status of epidermal Heparanase 2 expression $(\mathrm{P}=0.038)$. All lesional epidermal expression was negative while perilesional epidermal expression was negative in $24(80 \%)$ cases and positive in $6(20 \%)$ cases, control epidermal expression was negative in $27(90 \%)$ cases and positive in $3(10 \%)$ cases. There was no significant difference between the three studied groups regarding dermal Heparanase 2 expression $(\mathrm{P}=0.318)$.

Conclusion: Downregulation of Heparanase 2 could be incriminated in the pathogenesis of psoriasis. Heparanase 2 could have a protective role in skin.

Keywords: Heparanase2, Psoriasis, Downregulation, protective.

\section{INTRODUCTION}

Psoriasis is a chronic, inflammatory immune mediated skin disease ${ }^{(\mathbf{1})}$. It is characterized by development of erythematous, indurated, scaly, pruritic skin plaques and its pathogenesis is driven by proinflammatory cytokines ${ }^{(2)}$. Psoriasis prevalence is now in increase. It is a serious dermatological disease extending beyond the physical symptoms as it exerts significant, negative impact on patients' quality of life ${ }^{(3)}$.

In psoriasis heparanase acts through facilitation of pathologic crosstalk between keratinocyte and immunocyte communication circuits through activation of macrophages and other cells of innate immunity at the site of inflammation following degradation of heparan sulphate in the basement membrane and extracellular matrix ${ }^{(4)}$.

Hparanase 2 retains the capacity to bind heparin/heparin sulphate (HS) and, importantly, exhibits an even higher affinity toward heparin/HS than heparanase 1, thus competing for HS binding and inhibiting heparanase 1 enzymatic activity. Moreover, coimmunoprecipitation studies revealed physical association between Hparanase2 and heparanase1 proteins, providing additional explanation for the inhibition of heparanase 1 enzymatic activity by Hparanase $2^{(5)}$.

Aim of our study is to assess the role of Heparanase 2 in psoriasis through its immunohistochemical expression in lesional and perilesional skin of psoriasis patients and control skin.

\begin{abstract}
PATIENTS AND METHODS
This is a prospective case control study carried out on a total number of 60 subjects, they included 30 patients with chronic plaque psoriasis attending the Menoufia skin and andrology outpatient clinic during the period between June 2019 to June 2020 and 30 age and gender matched apparently normal subjects as control group.
\end{abstract}

\section{Ethical approval:}

The study was approved from the ethical committee of Faculty of Medicine Menoufia University and the patients gave an informed consent. Skin biopsies were taken for immunohistochemical evaluation of Heparanase 2 expression.

\section{Clinical data:}

All study subjects were subjected to the following after taking written consent: complete history tacking, complete general examination, dermatological examination with determination of site, size, number, type, extent, distribution of the lesions, assessment of Psoriasis Area and Severity Index (PASI) score. 


\section{Tissue biopsy:}

Biopsies were taken by $3 \mathrm{~mm}$ punch biopsies under complete aseptic condition. Biopsies were fixed in neutral formalin $10 \%$ and were submitted to routine tissue processing ending with paraffin embedded blocks formation in Pathology Department, Faculty of Medicine, Menoufia University.

\section{Immunohistochemistry technique:}

Two $4 \mu$ paraffin sections were cut from each block and mounted on positively charged glass slides to be ready for immunohistochemical staining using streptavidin-biotin amplified system. The primary antibody was concentrated rabbit polyclonal antiHeparanase2 antibody (Cat .No.YPA1662) (Chongqing Biospes Co., Ltd, Room 27-2, Building 7, No.15, Paradise Walk, Jiangbei District, Chongqing, 400039, China). It was diluted 1: 100 using EDTA. Ultra V block was applied to block nonspecific background staining. Antigen retrieval was performed using Tris-EDTA (ph 9).

The detection kit was ultravision detection system antipolyvalent HRP/DAB (ready to use, cat. \#TP-015-HD; Lab vision corporation, Fermont, California). Finally the reaction can be visualized by appropriate substrate/chromogen (Diaminobenzidine, DAB) reagent with Mayer's hematoxylin as counterstain. The staining procedure included positive tissue control (breast tissue) and negative tissue controls omitting the primary antibodies.

\section{Interpretation of immunostaining results:}

Expression of Heparanase 2 in both epidermis and dermis was assessed in the three studied groups. Status, topographic pattern of expression (nuclear or cytoplasmic) and intensity of staining were assessed.

The intensity of staining was ranked as: 0 , no staining; +1 , mild intensity; +2 , moderate intensity; +3 strong intensity ${ }^{(6)}$.

$\mathrm{H}$ score system was applied according to Han $\boldsymbol{e t}$ al. ${ }^{(7)}$, where both the intensity and percentage of positivity were considered using the following formula:

$\mathrm{H}$ score $=(3 \times \%$ of strong intensity $)+(2 \times \%$ of moderate intensity $)+(1 \times \%$ of mild intensity $)$.

Statistical analysis was conducted using Statistical Package for Social Science (IBM SPSS) version 23. Chi-square test and/or Fisher exact test, Independent t-test. F- test (ANOVA) and Pearson coefficients were used. $\mathrm{P}$ value up to 0.05 is considered statistically significant and $\mathrm{P}$ value less than 0.001 is considered highly significant.

\section{RESULTS}

Clinical data of the included psoriatic cases were listed in table (1).

Table (1): Clinical data among psoriasis group.

\begin{tabular}{|c|c|}
\hline Parameters & $\begin{array}{l}\text { Psoriasis group } \\
\text { No }=30 \\
\text { No }(\%)\end{array}$ \\
\hline $\begin{array}{l}\text { Gender } \\
\text { Male } \\
\text { Female }\end{array}$ & $\begin{array}{l}17(56.7) \\
13(43.3)\end{array}$ \\
\hline $\begin{array}{l}\text { Age (years) } \\
\text { Min. - Max. } \\
\text { Mean } \pm \text { SD. } \\
\text { Median }\end{array}$ & $\begin{array}{l}15-75 \\
40.57 \pm 17.32 \\
38\end{array}$ \\
\hline $\begin{array}{l}\text { Course } \\
\text { Stationary } \\
\text { Progressive }\end{array}$ & $\begin{array}{l}9(10) \\
21(23.3)\end{array}$ \\
\hline $\begin{array}{l}\text { Family History } \\
\text { Positive } \\
\text { Negative }\end{array}$ & $\begin{array}{l}8(26.7) \\
22(73.3)\end{array}$ \\
\hline $\begin{array}{l}\text { Smoking } \\
\text { Positive } \\
\text { Negative }\end{array}$ & $\begin{array}{l}9(30) \\
21(70)\end{array}$ \\
\hline $\begin{array}{l}\text { Medical diseases } \\
\text { Positive } \\
\text { Negative }\end{array}$ & $\begin{array}{l}8(26.7) \\
22(73.3)\end{array}$ \\
\hline $\begin{array}{l}\text { Type of medical disease } \\
\text { DM } \\
\text { HTN (mmHg) } \\
\text { Rheumatoid arthritis }\end{array}$ & $\begin{array}{l}\text { No = 8 } \\
4(50) \\
3(37.5) \\
1(12.5) \\
\end{array}$ \\
\hline $\begin{array}{l}\text { Sites } \\
\text { Extremities } \\
\text { Trunk +extremities } \\
\text { All over the body }\end{array}$ & $\begin{array}{l}3(10) \\
11(36.7) \\
16(53.3)\end{array}$ \\
\hline $\begin{array}{l}\text { PASI Score } \\
\text { Min. - Max. } \\
\text { Mean } \pm \text { SD. } \\
\text { Median (IQR) }\end{array}$ & $\begin{array}{l}2-42.30 \\
15.46 \pm 10.98 \\
11.85\end{array}$ \\
\hline
\end{tabular}

Min: Minimum Max: Maximum DM: Diabetes mellitus NO: Number SD: Standard Deviation HTN: Hypertension

Immunohistochemical expression of Heparanase 2 in lesional, perilesional and control groups was as following:

In control group; epidermal expression of Heparanase 2 was negative in $27(90 \%)$ cases while it was positive in $3(10 \%)$ cases with mild diffuse cytoplasmic pattern, $\mathrm{H}$ score ranged from 10 to 20 with mean \pm SD of $16.67 \pm 5.77$. Dermal expression of Heparanase 2 was negative in $27(90 \%)$ cases while it was positive in $3(10 \%)$ cases with mild diffuse cytoplasmic pattern also. $\mathrm{H}$ score ranged from 60 to 80 with mean \pm SD of $70 \pm 10$. (Figure 1) 


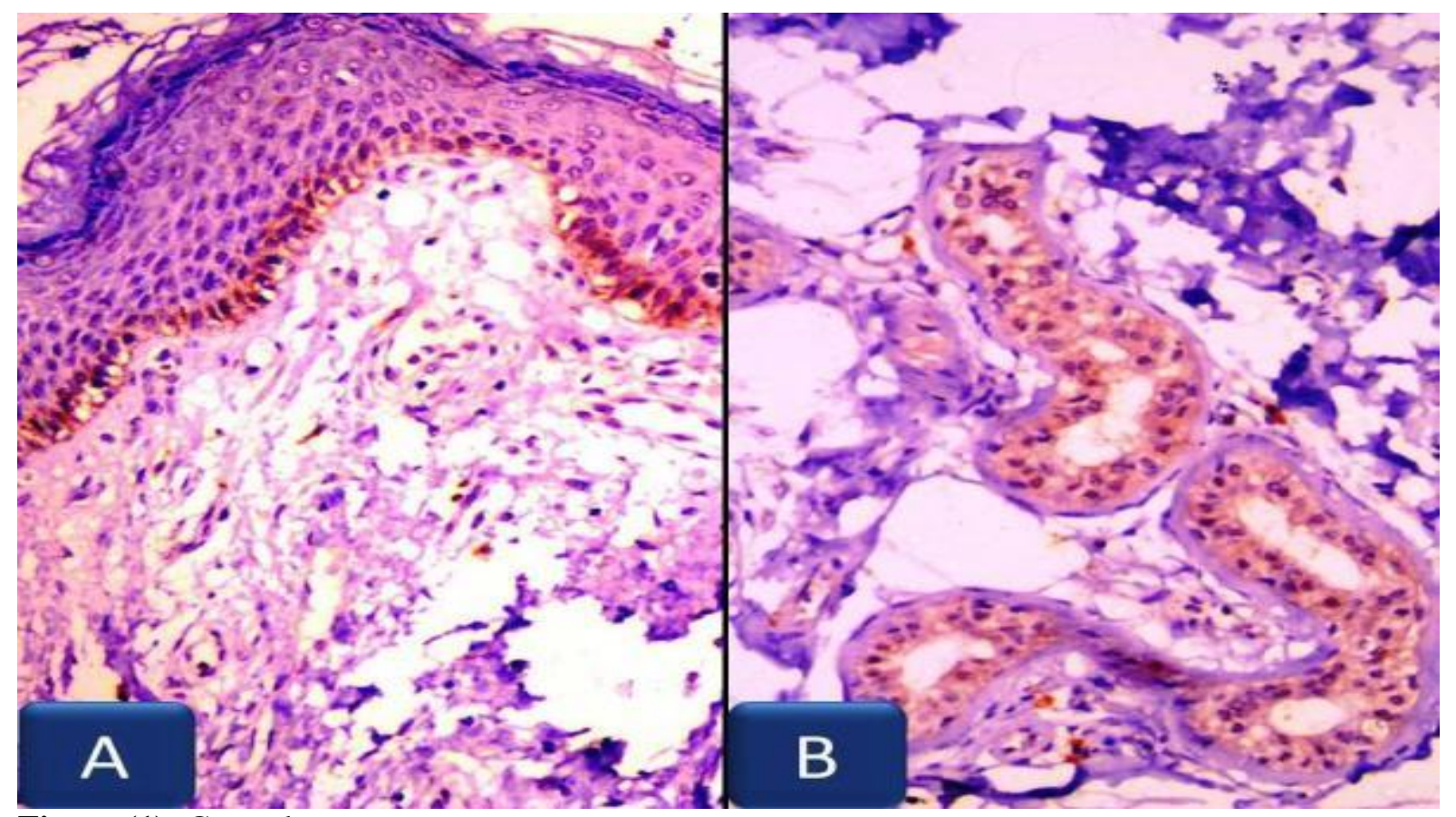

Figure (1): Control group:

(A) Positive diffuse cytoplasmic Heparanase 2 expression in basal cell layer of epidermis. (B) Positive diffuse cytoplasmic Heparanase 2 expression in eccrine sweat glands ducts. (Heparanase $2 \mathrm{IHC} \times 100$ for A and B).

In perilesional psoriatic skin; epidermal expression of Heparanase 2 was negative in $24(80 \%)$ cases while it was positive in $6(20 \%)$ cases with mild diffuse cytoplasmic pattern. Epidermal $\mathrm{H}$ score ranged from 10 to 20 with mean \pm SD of $15 \pm 5$.48. Dermal expression of Heparanase 2 was negative in 29 cases $(96.7 \%)$ while it was positive in only one case $(3.3 \%)$ with mild diffuse cytoplasmic pattern. Dermal H score was 20 with mean \pm SD of 20. (Figure 2)

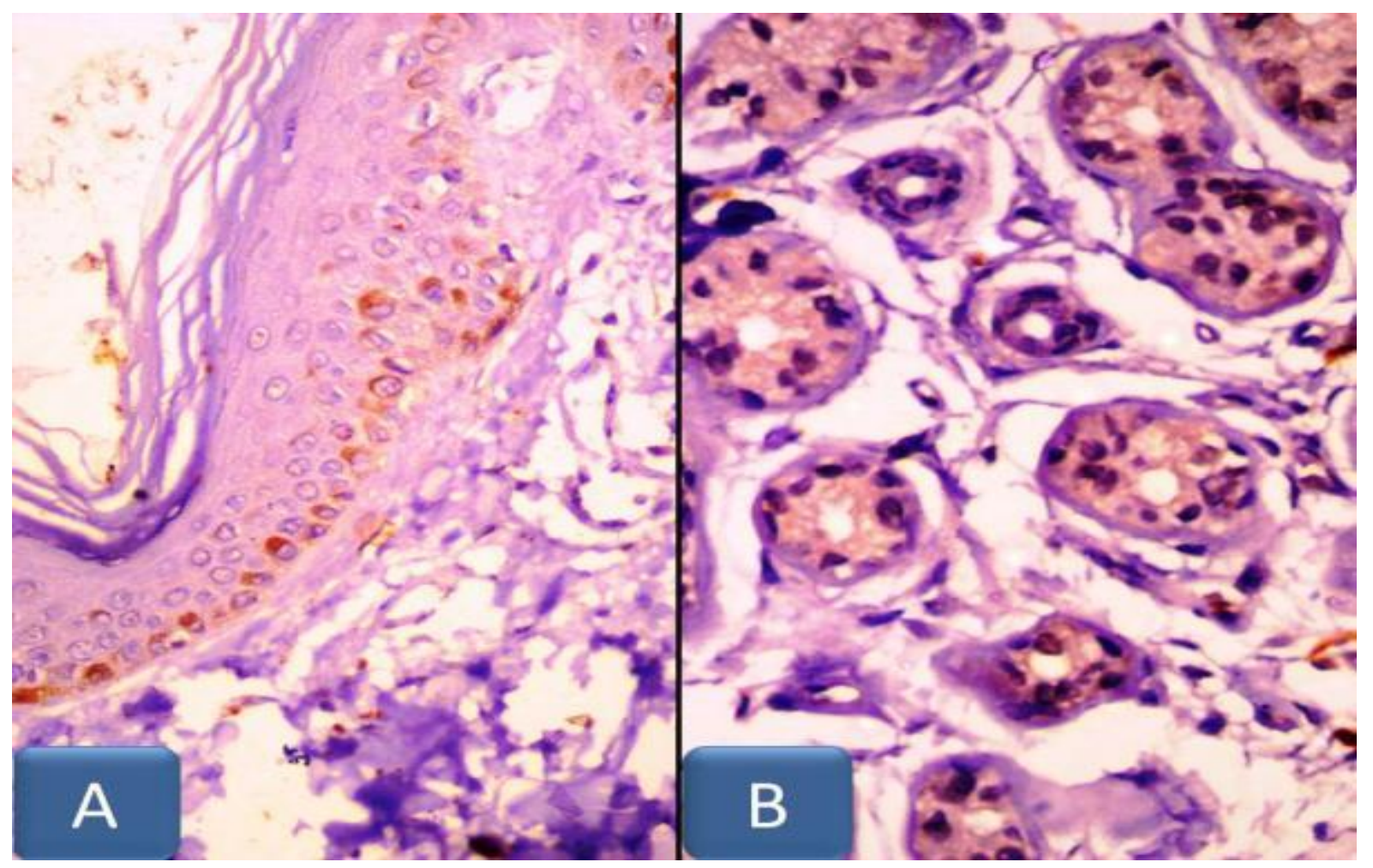

Figure (2): Perilesional skin:

(A) Mild positive cytoplasmic Heparanase 2 expression in basal cell layer of epidermis.

(B) Mild positive cytoplasmic Heparanase 2 expression in eccrine sweat gland ducts. (Heparanase 2 IHC $\times 100$ for $A$ and $B$ ).

In lesional psoriatic skin; all cases showed negative expression both in epidermis and dermis. (Figure 3) 


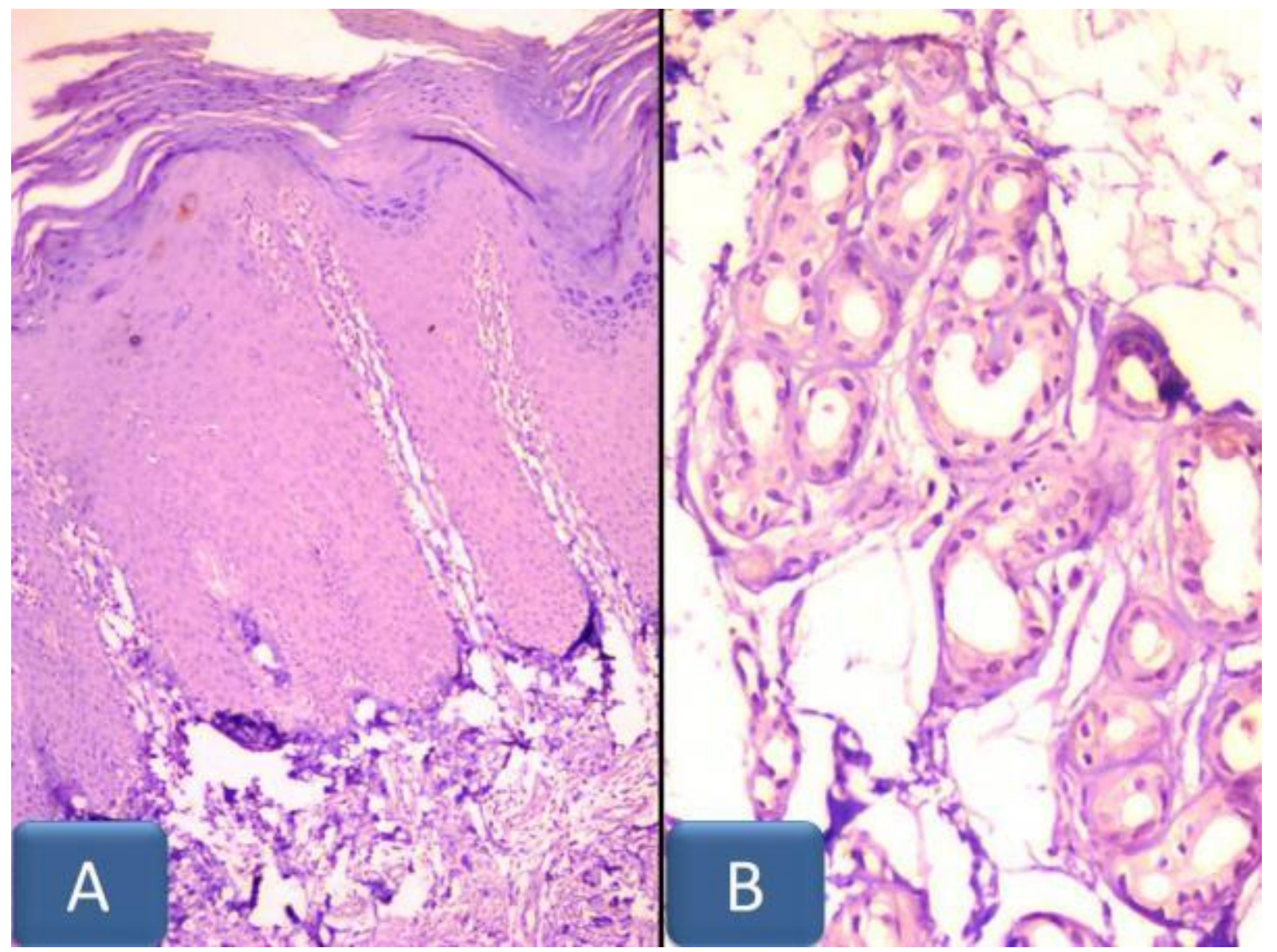

Figure (3): Psoriatic skin:

(A) Complete absence of Heparanase 2 in all layers of epidermis

(B) Complete absence of Heparanase 2 in eccrine sweat gland ducts. (Heparanase 2 IHC $\times 100$ for A and B).

Comparison between the three studied groups regarding epidermal Heparanase2 expression (Table 2) There was significant difference between lesional, perilesional and control groups regarding the status of epidermal Heparanase 2 expression $(\mathrm{P}=0.038$ ) (Figure 4)

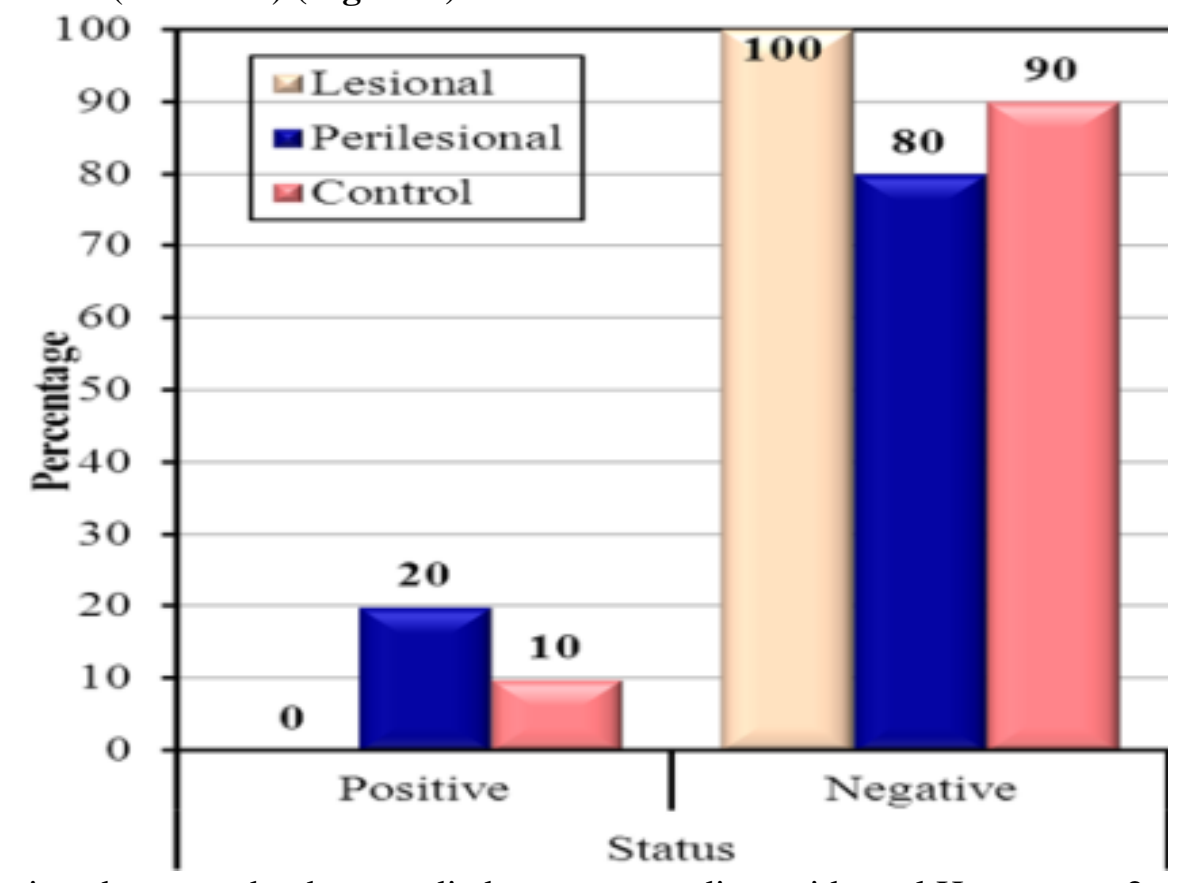

Figure (4): Comparison between the three studied groups regarding epidermal Heparanase 2 expression Comparison between the three studied groups regarding dermal Heparanase 2 expression (Table3)

There was no significant difference between lesional, perilesional and control groups regarding the status of dermal Heparanase 2 expression $(\mathrm{p}=0.318)$. 
Table (2): Comparison between the three studied groups regarding epidermal Heparanase2 expression.

\begin{tabular}{|c|c|c|c|c|c|}
\hline Parameters & $\begin{array}{c}\begin{array}{c}\text { Lesional } \\
(\text { No }=30)\end{array} \\
\text { No }(\%)\end{array}$ & $\begin{array}{c}\begin{array}{c}\text { Perilesional } \\
(\text { No }=30)\end{array} \\
\text { No }(\%)\end{array}$ & $\begin{array}{c}\begin{array}{c}\text { Control } \\
(\text { No }=30)\end{array} \\
\text { No }(\%) \\
\end{array}$ & $\begin{array}{c}\text { Test of } \\
\text { significance }\end{array}$ & $P$ value \\
\hline $\begin{array}{l}\text { Status } \\
\text { Positive } \\
\text { Negative }\end{array}$ & $\begin{array}{c}0(0) \\
30(100)\end{array}$ & $\begin{array}{c}6(20) \\
24(80)\end{array}$ & $\begin{array}{c}3(10) \\
27(90)\end{array}$ & $\begin{array}{c}\chi^{2}= \\
6.796\end{array}$ & $\begin{array}{c}\mathrm{p}= \\
0.038^{*} \mathbf{S}\end{array}$ \\
\hline Sig. bet. grps. & ${ }^{\mathrm{FE}} \mathrm{p}_{1}=\mathrm{C}$ & $\begin{array}{c}4^{*},{ }^{F E} \mathrm{p}_{2}=0.237 \\
\mathbf{N o}=\mathbf{6}\end{array}$ & $\begin{array}{r}\mathrm{S}_{3}=0.472 \\
\mathbf{N o}=\mathbf{3}\end{array}$ & & \\
\hline \begin{tabular}{|l|} 
Topography \\
Cytoplasmic \\
Nucleocytoplasmic \\
\end{tabular} & $\begin{array}{l}0(0) \\
0(0)\end{array}$ & $\begin{array}{c}6(100) \\
0(0)\end{array}$ & $\begin{array}{c}3(100) \\
0(0)\end{array}$ & NA & - \\
\hline \begin{tabular}{|l|} 
Intensity of staining \\
Mild \\
Moderate \\
Strong \\
\end{tabular} & $\begin{array}{l}0(0) \\
0(0) \\
0(0)\end{array}$ & $\begin{array}{l}6(100) \\
0(0) \\
0(0)\end{array}$ & $\begin{array}{c}3(100) \\
0(0) \\
0(0)\end{array}$ & NA & - \\
\hline $\begin{array}{l}\text { H score } \\
\text { Min. - Max. } \\
\text { Mean } \pm \text { SD. } \\
\text { Median }\end{array}$ & $\begin{array}{l}- \\
- \\
-\end{array}$ & $\begin{array}{c}10-20 \\
15 \pm 5.48 \\
15\end{array}$ & $\begin{array}{c}10-20 \\
16.67 \pm 5.77 \\
20\end{array}$ & $\begin{array}{c}\mathrm{t}= \\
0.424\end{array}$ & $\begin{array}{c}0.685 \\
\text { NS }\end{array}$ \\
\hline
\end{tabular}

$\chi^{2}$ : Chi square test FE: Fisher Exact

p: $p$ value for comparing between the studied groups

$\mathrm{p}_{1}: \mathrm{p}$ value for comparing between Lesional and Perilesional

$\mathrm{p}_{2}: \mathrm{p}$ value for comparing between Lesional and Control

$\mathrm{p}_{3}: \mathrm{p}$ value for comparing between Perilesional and Control

*: Statistically significant at $\mathrm{p} \leq 0.05, \mathbf{S}$ : significant, NA: non applicable, No: Number

Table (3): Comparison between the three studied groups regarding dermal Heparanase 2 expression.

\begin{tabular}{|c|c|c|c|c|c|}
\hline \multirow[t]{2}{*}{ Parameters } & $\begin{array}{c}\text { Lesional } \\
(\mathrm{No}=30)\end{array}$ & $\begin{array}{c}\text { Perilesional } \\
(\text { No }=30)\end{array}$ & $\begin{array}{c}\text { Control } \\
(\mathrm{No}=30)\end{array}$ & \multirow{2}{*}{$\begin{array}{c}\text { Test of } \\
\text { significance }\end{array}$} & \multirow[t]{2}{*}{$P$ value } \\
\hline & No $(\%)$ & No $(\%)$ & No (\%) & & \\
\hline \multicolumn{6}{|l|}{ Status } \\
\hline Positive & $0(0)$ & $1(3.3)$ & $3(10)$ & $\chi^{2}=$ & $\mathrm{p}=$ \\
\hline \multirow[t]{2}{*}{ Negative } & 30 (100) & 29 (96.7) & $27(90)$ & 3.025 & 0.318 \\
\hline & & No $=1$ & No $=3$ & & \\
\hline Topography & & & & & \\
\hline Cytoplasmic & $0(0)$ & $1(100)$ & $3(100)$ & $\mathrm{N}$ & \\
\hline Nucleocytoplasmic & $0(0)$ & $0(0)$ & $0(0)$ & NA & - \\
\hline Intensity of staining & & & & & \\
\hline Mild & $0(0)$ & $1(100)$ & $3(100)$ & & \\
\hline Moderate & $0(0)$ & $0(0)$ & $0(0)$ & NA & - \\
\hline Strong & $0(0)$ & $0(0)$ & $0(0)$ & & \\
\hline H score & & & & & \\
\hline Min. - Max. & - & $20 \#$ & $60-80$ & $\mathrm{NA}$ & - \\
\hline Mean \pm SD & - & & $70 \pm 10$ & NA & - \\
\hline Median & - & & 70 & & \\
\hline H score category & & & & & \\
\hline Low $(<150)$ & - & $1(100)$ & $3(100)$ & NA & - \\
\hline $\operatorname{High}(\geq 150)$ & - & $0(0)$ & $0(0)$ & & \\
\hline
\end{tabular}

$\chi^{\mathbf{2}}$ : Chi square test, $\mathbf{p}: \mathrm{p}$ value for comparing between the studied groups

*: Statistically significant at $\mathrm{p} \leq 0.05$

S: significant, NA: non applicable, No: Number

\#: Excluded from the comparison due to small number of case $(\mathrm{No}=1)$ 


\section{DISCUSSION}

Psoriasis is a chronic inflammatory disease of the skin that affects about 2-3\% of the population and greatly impairs the quality of life of affected individuals. Psoriatic skin is characterized by excessive proliferation and aberrant differentiation of keratinocytes, as well as redness caused by increased dilation of the dermal blood vessels and infiltration of immune cells. Although the pathogenesis of psoriasis has not yet been completely elucidated, it is generally believed to arise from a complex interplay between hyperproliferating keratinocytes and infiltrating, activated immune cells ${ }^{(\mathbf{8})}$.

The aim of our study is to explore the role of Heparanase 2 in psoriasis.

Heparanase resides in the endosomal/lysosomal compartment for a relatively long time and is likely to play a role in the normal turnover of heparan sulphate ${ }^{\left({ }^{(9)}\right.}$. Heparan sulphate is located mainly in basement membrane at dermoepidermal junction of normal skin explaining the positive expression of Heparanase 2 in basal cell layer of the skin in normal control specimens ${ }^{\left({ }^{(10)}\right.}$. It is also involved in sweat gland morphogenesis in embryonic life explaining positive expression of Heparanase 2 in eccrine sweat gland ducts in normal control specimens ${ }^{(\mathbf{1 1})}$.

Residence and accumulation of heparanase in lysosomes indicates its function in the normal physiology of this organelle. Lysosomal heparanase has a role in augmenting autophagy, a physiological process required to remove unfolded proteins and damaged organelles, thus maintaining cellular homeostasis ${ }^{\mathbf{( 1 2})}$.

Keratinocytes is important source of heparanase in human psoriatic lesions ${ }^{(4)}$. Other cells including $\mathrm{T}$ lymphocytes, $\mathrm{B}$ lymphocytes, neutrophils, monocytes, endothelial cells and fibroblasts can also upregulate heparanase expression upon activation and thereby contribute to inflammation ${ }^{(\mathbf{1 2})}$.

Heparanase2 has no enzymatic activity and lacks intrinsic HS-degrading activity, the hallmark of heparanases which cause remodelling of extracellular matrix (ECM), basement membrane and affect several aspects of inflammatory reactions, such as leukocyte recruitment, extravasation and migration towards inflammation sites; release of cytokines and chemokines anchored within the ECM or cell surfaces, as well as activation of innate immune cells (12). Heparanase1 also was involved in pathogenesis of psoriasis by stimulating macrophage activation (the source of TNF- $\alpha)^{(4)}$, regulating the transcription of proangiogenic vascular endothelial growth factor (VEGF), matrix metallopeptidase 9 (MMP-9) and proinflammatory chemical mediators $(\mathrm{TNF} \alpha, \mathrm{IL}-1$ and IL-6) ${ }^{(5)}$.
Although Heparanase2 has no enzymatic activity but it retains the capacity to bind heparin/ HS and importantly exhibits an even higher affinity towards heparin/HS than Heparenase1 thus competing for HS binding and inhibiting Heparenase 1 enzymatic activity ${ }^{(9)}$.

The higher affinity for HS has been proposed to allow HPSE2 to out-compete for and displace HPSE1 substrate binding ${ }^{(\mathbf{1 3})}$.

Recent developments in biology of Heparanase 2 stated that Heparanase 2 not only inhibits Heparanase1 activity but also regulates selected genes that affect tissue vascularity, fibrosis, cell differentiation resulting in inflammation suppression ${ }^{(14)}$. It also inhibits neovascularization mediated by vascular endothelial growth factor (VEGF) ${ }^{(9)}$.

In our study Heparanase 2 was downregulated (negative immunohistochemical expression) in lesional psoriatic skin suggesting lost function of inhibiting and displacing heparanase 1 from its binding sites allowing inflammatory psoriatic process to take place.

To our best knowledge, thorough search in English literature revealed that this is the first study that assess immunohistochemical expression of Heparanase 2 in psoriasis and in normal skin also. Scarce articles was identified studding the role of heparanase 1 in cutaneous inflammatory conditions like psoriasis and their results were supportive to us as heparanase 1 was markedly overexpressed in lesional psoriatic skin and they backed up their results by experimental studies on mice which found that heparanase 1 overexpression preserves psoriasis like phenotype in mouse skin following tetradecanoyl phorbol 12-myristate 13-acetate (tpa) application ${ }^{(4)}$.

Heparanase 1 also has a role in non-cutaneous inflammatory conditions. It was identified in Crohn' disease ${ }^{(\mathbf{1 5})}$, in synovial tissue of rheumatoid arthritis patients ${ }^{(16)}$ and in plaque tissue of atherosclerosis ${ }^{(\mathbf{1 7})}$.

\section{CONCLUSION}

Downregulation of Heparanase 2 could be incriminated in the pathogenesis of psoriasis. Heparanase 2 could have a protective role against immunological insult in psoriasis.

\section{REFERENCES:}

1. Sil P, Wong S, Martinez J (2018): More than skin deep: autophagy is vital for skin barrier function. Front. Immunol., 9: 1376-83.

2. Korman $\mathbf{N}$ (2020): Management of psoriasis as a systemic disease: what is the evidence. Brit. J. Dermatol., 182(4): 840-848.

3. Sharaf A, Ibrahim A (2017): Quality of life of patients with Psoriasis in Alexandria- Egypt. IOSR Journal of Nursing Health Science, 6(1): 17-29. 
4. Lerner I, Zcharia E, Neuman T et al. (2014): Heparanase is preferentially expressed in human psoriatic lesions induces development of psoriasiform skin inflammation in mice. Cell. Mol. Life Sci., 71(12): 2347-2357.

5. Vlodavsky I, Gross-Cohen $M$, Weissmann $M$ et al. (2018): Opposing functions of heparanase-1 heparanase-2 in cancer progression. Trends Biochem. Sci., 43(1): 18-31.

6. Gross-Cohen M, Feld S, Naroditsky I et al. (2016): Heparanase 2 expression inversely correlates with bladder carcinoma grade stage. Oncotarget,7(16):22556.

7. Han S, Bai E, Jin G et al. (2014): Expression clinical significance of YAP, TAZ, AREG in hepatocellular carcinoma. J Immunol Res., 2014, 261365.

8. Afonina I, Van Nuffel E, Beyaert R (2021): Immune responses therapeutic options in psoriasis. Cellular molecular life science. https://www.researchgate.net/publication/34816 0697_Immune_responses_and_therapeutic_optio ns_in_psoriasis

9. Pinhal M, Melo C, Nader $\mathrm{H}$ et al. (2020): The Good Bad Sides of Heparanase-1 Heparanase-2. Heparanase. Springer, Cham. https://pubmed.ncbi.nlm.nih.gov/32274740/

10. Iriyama $S$, Hiruma $T$, Tsunenaga $M$ et al. (2011): Influence of heparan sulfate chains in proteoglycan at the dermal-epidermal junction on epidermal homeostasis. Exp. Dermatol., 20(10):810-4.

11. Coulson T (2016): The role of heparan sulphate in development: the ectodermal story. Int. J. Exp. Pathol., 97(3):213-229.

12. Vlodavsky I, Singh P, Boyango I et al. (2016): Heparanase: From basic research to therapeutic applications in cancer inflammation. Drug resist Updat., 29: 54-75.

13. Mckenzie E (2020): Hpa 2 Gene Cloning. In: Heparanase. Springer, Cham, in: Advances in Experimental Medicine and Biology https://link.springer.com/chapter/10.1007\%2F97 8-3-030-34521-1_34

14. Jin H, Cui $\bar{M}$ (2018): New advances of Heparanase Heparanase-2 in human diseases. Archives of Medical Research, 49(7): 423-429.

15. Waterman M, Ben-Izhak O, Eliakim $\mathrm{R}$ et al. (2007): Heparanase upregulation by colonic epithelium in inflammatory bowel disease. Mod Pathol., 20(1):8-14.

16. Li R, Craig F, Di Y et al. (2008): Dramatic regulation of heparanase activity angiogenesis gene expression in synovium from patients with rheumatoid arthritis. Arthritis \& Rheum., 58(6): 1590-1600.

17. Osterholm C, Folkersen $L$, Lengquist $M$ et al. (2013): Increased expression of heparanase in symptomatic carotid atherosclerosis. Atherosclerosis, 226(1):67-73. 